\title{
An Overview of Issues and Research in Language Learning in a Study Abroad Setting ${ }^{1}$
}

\author{
B a r b a r a F. F r e e d \\ Carnegie Mellon University
}

\section{Introduction}

It has long been assumed that the combination of immersion in the native speech community, combined with formal classroom learning, creates the best environment for learning a second language. The power of this assumption is so great that there has evolved a popular belief, one shared by students and teachers, parents and administrators, that students who spend a period abroad are those who will ultimately become the most proficient in the use of their language of specialization. Consequently, hundreds of thousands of students depart annually for education abroad experiences with the expectation that they too will "pick up" if not become "fluent" in the target languages they have chosen to study, returning home with greatly enhanced language skills.

Unfortunately, these popular perceptions aside, relatively little scholarly attention has been devoted to documenting changes in the communicative language proficiency of students who have studied abroad. Similarly, little research has focused on examining the actual experiences that students have in the context of their sojourn abroad. The purpose of this chapter therefore, is to review what is currently known about second language acquisition (SLA) in a study abroad context and to identify some of the issues that confront those who wish to explore this topic in greater depth. 


\section{Language Learning and Study Abroad}

It is, indeed, often the case that the experience of residing in a country where the language spoken is other than one's own results in the learning of many aspects of the language of that country. However, the extent to which the language (be it oral or written) is learned, and the style and dialect that is acquired, depends on numerous variables. In the case of American students studying abroad, these variables include striking individual differences in learning styles, motivation and aptitude, the features of the specific language to be learned, the degree to which they are actually "immersed" in the native speech community and the interaction of these variables with formal classroom instruction in the study abroad context.

Since the late 1960s a gradually increasing literature has emerged which addresses the general topic of the linguistic impact of various types of study abroad experiences. The development and direction of this domain of research is a logical outgrowth of the maturing of the field of SLA in general, where scholars continue to refine their focus on the numerous variables (age, primary language, context of learning, purpose for study and motivation among others) that have been shown to affect the acquisition of non-primary languages. Research whose central focus has been language learning in a study abroad context has, for the most part, found support for the positive role played by an in-country experience for language learning. This research has focused on two general areas. The first relates to a continuum of language abilities — primarily oral but also literate — which might be affected by a study abroad experience. These include, for example, the development of oral proficiency, the use of communication strategies, the acquisition of fluency, the acquisition of sociolinguistic skills, the development of literacy skills, etc. The second addresses student perceptions of the study abroad experience and how those perceptions in turn impact their learning

The work to be discussed in this chapter is organized into two general categories. The first summarizes research which is almost exclusively based on the results of criterion-referenced tests to demonstrate the linguistic advantages of a sojourn abroad. The second, a far broader category with several sub-divisions, includes a diverse selection of research studies that examine both language development, as defined above, as well as 
student perceptions of the study-abroad living and learning experience. These combined categories serve to expand the scope of inquiry in this emerging area of second language acquisition research.

\section{Test-B a s ed $S t u d i e s$}

Prior to the early 1990s there were a series of sporadic and unrelated studies which explored the language learning experiences of students who had been abroad. With a few notable exceptions these studies relied almost exclusively on test scores to document the linguistic advantages of a period spent abroad. Prominent among these was John Carroll's (1967) study of the language proficiency of 2,782 college seniors majoring in French, German, Italian and Russian. Carroll found that time spent abroad was one of the major predictors of overall language proficiency. For many years this frequently cited study provided the major data which supported the belief that students who spend time in study abroad situations tend to acquire greater "proficiency" in the target language than those who do not.

In subsequent years, a scattering of small and largely uncontrolled studies appeared in Britain between 1969 and 1974. This work was briefly summarized by a team of British scholars who, in a prelude to their own study, lamented the lack of "systematic investigations of the effects upon linguists of a period of residence abroad" (Willis, Doble, Sankarayya and Smithers 1977: 5). Willis and his colleagues subsequently carried out their own project in which they examined linguistic growth (once again, as measured by test scores) in speaking, listening and reading of 88 British students who spent more than a year either working or studying in France or Germany. Despite the self-acclaimed limitations of their study, the preresidence/post-residence tests provided the anticipated support for a period of study or residence abroad.

Similar support is reported in a series of more recent British studies which evidence expanding concern and interest in this topic. In the first of these, Dyson (1988) assessed the listening and speaking skills of 229 British students who had spent a year studying in France, Germany, or Spain. The pre- to post-test scores indicated considerable growth in both these skills, particularly among the weaker students in the study. Unfortunately, the study lacks comparative data on students who had not 
been abroad. Thus, as Dyson acknowledges, it is not possible to compare their improvement (in linguistic competence) with any that might have resulted from an extra year of study spent at home (1988:18).

Throughout the 1980s a number of researchers utilized the ACTFL/ILR Oral Proficiency Interview (OPI) as a criterion measure for analyzing changes in oral proficiency for students who had been abroad. Among the earliest of these, Veguez (1984), analyzed the language growth of 17 Middlebury College students who studied in Spain and found that they progressed on the OPI from ratings of Intermediate-Mid or High to Intermediate-High or Advanced. In a study which provided a control group, Liskin-Gasparro (1984) compared two groups of students who were studying Spanish and found that those who had been abroad rated higher on the OPI than those who had not. Magnan (1986) used the OPI to evaluate American students of French who had foreign study experience and noted that those who had been abroad scored higher on the OPI than those who had remained at home. In 1988 O'Connor conducted a study of some 30 students, again from Middlebury College, who spent a year in France and found that, at the end of the year, the students had moved from ratings of Intermediate-Mid or High to Intermediate-High or Advanced. Milleret (1990) conducted a similar study of eleven students of Portuguese using the Portuguese Speaking Test (a pre-recorded oral proficiency interview based on the ACTFL OPI, but administered in a language laboratory to groups rather than individuals). Milleret found that students who participated in a six-week summer abroad program in Brazil moved, on the average, from the equivalent of an Intermediate-Mid to an Intermediate-High on the ACTFL scale. More recently Foltz (1991) used the OPI to assess the progress of a group of students who studied in Spain as compared to a comparable group who remained on campus. His results, as demonstrated by OPI scores, once again demonstrated greater growth in oral proficiency by those who participated in the study abroad program.

Complementing these studies, whose subjects were American students who spent a period of time in overseas educational programs, are those which analyze language learning in the context of Canadian interprovincial exchanges. Several of these (Clement 1978; Gardner et al. 1978; Hanna et al. 1980) have shown that involvement in an exchange program affects students' motivation and also has a positive impact on their second language proficiency. Program evaluation research undertak- 
en by the Modern Language Centre at the Ontario Institute for Studies in Education explored the relationship of visits to French-dominant areas to the tested French proficiency of some 1,000 students in grades 8 and 12 . Among the findings which emerged from these studies were that grade 8 students who have visited a French dominant area, on average, obtained higher scores on tests of listening comprehension, and that some of these students (those in middle immersion programs) received higher scores on fluency measures of the speaking tests. However, in grade 12, no differences in tested proficiency appear in relation to students' visits to Frenchspeaking areas. The authors of this report conclude that time spent in the native speech community will enhance second language proficiency, particularly with respect to oral skills.

Each of these studies points to the general linguistic advantages that may be derived from an academic stay abroad and has contributed preliminary knowledge to our understanding of the interaction between a stay abroad and formal classroom study. However these studies are somewhat limited by the fact that they rely exclusively on test scores to measure linguistic skills. Studies such as these seem to point to a strong positive correlation between second language growth and time spent abroad, therefore serving to reinforce our belief in the linguistic advantages of study abroad experiences. However, they reveal little, if anything, about specific qualitative changes in students' language proficiency. Such tests are descriptively inadequate and are unable to capture distinctions in linguistic usage that may result from an opportunity to live and study abroad. Moreover, as has been pointed out by Kaplan (1989), Freed (1990), Veguez (1984), Milleret (1990) and Hart et al. (1994), there are limitations in the use of discrete point tests such as the College Entrance Examination Board (CEEB) or the MLA Cooperative Tests, each of which result in potentially confounding ceiling effects. There are also many frequently-cited criticisms of the OPI. Among these are the fact that the OPI presents one global holistic score for many components of language use and, because of its non-linear construction, is often unable to discriminate progress made by students at the upper levels of the proficiency scale.

These shortcomings, coupled with the fact that many of the early studies were of excessively short duration and frequently lacked control groups, further limit their significance with respect to describing the linguistic growth of students who have spent time in an overseas context. As 
a group, these studies were unable to contribute to our understanding of the actual linguistic profile of students who have participated in education abroad programs. Nonetheless they served to stimulate interest in the topic and laid the groundwork for research which was to follow.

\section{Enhanced Format Studies}

Building upon the body of data which used several different types of test scores to suggest the linguistic advantages of study abroad, a more recent group of studies approach the questions of second language acquisition in a study abroad context from a variety of perspectives. Included among these are a series of major multi-dimensional projects as well as an interesting collection of individual studies which focus on specific linguistic features. Each of these categories will be discussed in turn.

\section{Multi-dimensional Studies}

The group of studies to be discussed in this section focuses on large scale studies, conducted primarily by American scholars who investigate the learning of American students abroad. However, it will also provide references to work by international scholars who concentrate on the language learning experiences of students within a European context.

By far the largest and most comprehensive study completed by American scholars to date is the multi-year, multi-institution study of Russian in a study abroad setting. This major statistical study combined quantitative and qualitative evaluation instruments to compare language learning abroad with that which occurs at home. Several individual and joint publications (Brecht and Davidson 1991; Brecht, Davidson and Ginsberg 1990 and 1993; Brecht and Robinson 1993; Ginsberg, Robin and Wheeling 1992; Ginsberg 1992), describe various aspects of this project. A brief summary of these findings includes the following:

1. Language aptitude, as measured by the Modern Language Aptitude Test (MLAT), is very strongly and positively related to reading gain, but otherwise has no significant correlation with gains in speaking or listening skills (Brecht and Davidson 1991:15).

2. Study abroad, as measured by the OPI, is an effective mode for learning to speak (Russian), particularly when compared to the proficien- 
cy attained by the typical student in a four-year college (Russian) program in this country (Brecht and Davidson 1991:16).

3. The higher the scores on the pre-reading/grammar tests, the more likely students are to gain in all other skills: speaking, listening, and reading. The authors claim that "this is the first substantial evidence for the common conviction that communication skills are most effectively built upon a solid grammar/reading base" (Brecht and Davidson 1991:16).

4. Higher levels of preprogram reading proficiency seem to facilitate gains on the OPI and listening (Brecht, Davidson and Ginsberg 1993: 17).

5. Men are more likely than women to gain on listening, and to advance on the OPI (Brecht, Davidson and Ginsberg 1993: 16.)

While much of research on the language learning and study abroad has described the language learning of American undergraduates studying abroad, an important complementary body of work, conducted by scholars working abroad, contributes to our understanding of language acquisition which occurs in an international context. A brief summary of this research follows but it is considered in great depth in Coleman's article in this volume.

Among the studies conducted in Europe, Meara (1994) excerpted the data which focused on the impact of study abroad from the more general Nuffield Modern Languages Inquiry. The Nuffield Inquiry did not gather data which objectively measured students' ability to use the target language, but did include 13 self-assessment or attitudinal questions which dealt with various components of the study abroad experience for the 586 student participants. The self-report data indicate that the majority of students felt that their oral-aural skills had improved as a result of the year abroad experience, but fewer than half of them believed that they had made similar progress in reading and writing skills. Noting the lack of carefully-controlled studies of the year abroad experience and the European community's commitment to promoting large scale mobility among students through its ERASMUS and SOCRATES programs (coordinated European Union efforts to organize exchanges and to encourage mobility among students, largely through grants for individual students), Meara cautions that "our current belief in the importance of a year abroad rests on some very flimsy, and largely anecdotal evidence" (1994:38).

A major step in bolstering understanding of the linguistic benefits of these inter-European exchanges is underway in the context of a three- 
stage multi-university project known as the European Language Proficiency Survey (Coleman, 1996, 1997a/b and this volume). This project, the largest of its kind ever undertaken, involves thousands of students in some 100 institutions. It includes a series of collaborative surveys and experiments, primarily quantitative and cross-sectional in nature, which assess linguistic skills, attitudes, anxiety and motivation related to language learning and the year abroad. Pilot studies, as reported by Coleman and his colleagues (1994 and this volume) provide, in addition to the usual support for linguistic progress during the year abroad, some new data which suggest that student growth in the target language slows down radically upon their return from a year abroad.

\section{Individual Research Studies}

In contrast to the large format studies summarized above, a group of individual projects, conducted in various parts of the world, has focused on specific aspects of language acquisition by students who have spent time in a study abroad setting. To a large degree, this work has refined the questions to be asked in accordance with many of the variables commonly identified in SLA research. The research to be considered is organized into several related sub-groupings, focusing primarily on the learning of various languages by American students who have had an opportunity to study abroad.

Among the earliest of the linguistically-focused analyses were the small case studies carried out by Möhle (1984) Raupach (1984, 1987), and Möhle and Raupach (1983). Their work responds to the common perception that the only way to learn to speak a language is by studying abroad. The results which emerge from this integrated series of studies suggests that what students most gain is some type of global fluency: the ability to "sound good" by increasing the rate of speech and/or decreasing the length of time between utterances, and by learning appropriate fillers, modifiers, formulae and compensation strategies, all of which provide them with a series of "native-sounding” attributes. Möhle and Raupach's work includes two companion sets of studies which analyze the learning of French by German students and the learning of German by French students. With respect to the German students in France, their findings were that "grammar, in terms of frequency of mistakes, or length and syntactic 
complexity of sentences, did not change in any noticeable way as a result of several months spent in France." There was a change, however, in the speech rate and the length of time between utterances. These same findings were not, however, replicated in the companion studies of French learners of German.

DeKeyser $(1986,1991)$ further expanded the initiative to closely analyze the influence of an overseas experience on the language learning of a small group of students. In an effort to understand how learners use their second language knowledge in actual communication, and how learners compensate for gaps in their knowledge DeKeyser compared the language skills of a group of American students who spent a semester in Spain with a comparable group who remained at home. His general finding was that, despite gains in fluency and vocabulary for the group in Spain, there were no significant differences found "between learning language in the classroom and picking it up abroad, or between grammar and oral proficiency." DeKeyser did find, however, important individual differences within the overseas groups, differences which "had a strong impact on the way the learners were perceived by native speakers" (1991:115). This focus on individual differences was to become a theme in much of the study abroad literature which emerged in the 1990s.

In the course of the early 1990s a number of small scale studies, once again both in the United States and abroad, have looked at specific aspects of second language acquisition in a study abroad setting. For example, Ryan and Lafford (1992) conducted a longitudinal analysis of the acquisition order of the Spanish verbs (ser and estar) by American students in a study abroad context. The goal of these authors was to compare their findings with those of prior studies which have investigated the acquisition order of these same features in a language classroom setting. Their results suggest an acquisition order similar, but not identical, to those established by VanPatten (1987). (VanPatten identified five stages of acquisition of the copula, beginning with the total absence of the copula in speech and moving toward the acquisition of the major functions of both the ser and estar forms: the progressive, the locative and the conditional). In those instances where Ryan and Lafford's results are at a variance with those posited by VanPatten, the authors' explanation for observed differences is that students in the study abroad setting are "exposed to more natural input than can be provided in the classroom" 
(Ryan and Lafford 1992: 721). Comparisons such as these, which examine qualitative differences in the language of students who study abroad as opposed to those whose learning is limited to the foreign language classroom, represent an important step in the direction of a more complete understanding of the impact of study abroad experiences on students' language learning.

A companion set of studies (Guntermann, 1992a, 1992b, 1995) also explores the acquisition order of two sets of Spanish forms (ser vs. estar and por vs. para). Unlike other studies, the data analyzed in this study is based on the language learning experiences of American Peace Corps volunteers, a special group of "study abroad" participants. Of particular interest is the "ser/estar" study, which provides yet another analysis of the acquisition order of these forms by the Peace Corps volunteers in an eight -to-ten week intensive language learning situation in Latin America. The results of this study provide general support for most of the stages postulated by prior researchers who looked both at the acquisition of these forms in the classroom (VanPatten, 1987) and in the study abroad context (Ryan and Lafford, 1992). Of equal interest is a finding similar to DeKeyser's, which emphasizes individual variation in acquisition.

Outside of the United States there has also been increasing activity by researchers engaged in studies of the linguistic impact of study abroad experiences. Several scholars have focused on the acquisition of Japanese by secondary level Australian students in exchange programs in Japan. Among these is a series of papers in which Marriott (1993a), and/or her colleagues, address the acquisition of sociolinguistic competence in this setting. Marriott and Enomoto (1995) analyze the discourse of two nonnative speakers of Japanese for the purpose of demonstrating deviations from appropriate politeness norms. Their preliminary findings suggest that the most difficult areas for these speakers involve the management of the speech acts of apology, compliments and requests. A second study (Marriott 1993b), focuses on the acquisition of a broader selection of sociolinguistic variables by 11 students who spent one year in Japan. The results of this study indicate great variation in the acquisition of sociolinguistic norms, with considerable deviation from expected norms even at the end of the year. Hashimoto's (1994) case study of one student in the homestay environment indicates that the student developed a sensitivity to the feature of variation in Japanese, but that it was not until her return 
to Australia that she began to incorporate variables of politeness into her speech. Research of this type was a precursor to larger studies of the acquisition of sociolingusitic competence to be discussed below and in far greater detail in Regan's article, which follows.

Milton and Meara's (1995) research on the growth of vocabulary (for German, French, Italian and Spanish students who spent a period studying in England) sheds new light on the dramatic increases made by these students during the time abroad. The 53 European exchange students who spent at least six months in the UK were found to acquire vocabulary "five times faster than for those who took classes at home ... and to be gaining vocabulary at a rate of over 2,500 words per year." (Despite these interesting findings, the reader is encouraged to see Meara, 1998.)

An additional group of publications addresses issues of language learning and study abroad from a slightly different perspective. The Swedish journal Finlance (Mauranen and Markkanen, 1994) includes a series of papers which focus primarily on the preparation of students for their out-of-country experience and difficulties encountered by students in the foreign classroom. Mauranen (1994), for example, documents the discourse problems that Finnish students encounter in discipline-specific courses when they are enrolled in the British classroom, problems that relate not to lexis or grammar, but rather to their insufficient knowledge of how to participate in the culturally-different discourse world of the British university classroom. Similarly, Ylönen (1994) compares the communicative situations that Finnish students encounter in scientific classrooms in Germany, suggesting that problems arise from distinct cultural differences in "study situations," most of which involve oral discourse in Germany but which tend to be in a written mode in Finland.

The mid-1990s brought a change in focus to much of the study abroad language learning literature. Evidence of this change was apparent in the publication of Second Language Acquisition in a Study Abroad Context (Freed, 1995a), the first book devoted to integrating a group of cross-linguistic studies which explored the relationship between language learning and the study abroad setting. At about the same time, a series of Ph.D. dissertations appeared which seemed to build upon the work of several of the scholars in this book. The research to be described below falls into four general areas: predicting and measuring language gains in study abroad settings; descriptions of the linguistic abilities which differentiate stu- 
dents who have been abroad from those whose language learning has been limited to the formal language classroom at home; the acquisition of sociolinguistic competence by students in immersion settings and student views of learning abroad.

\section{(1) Predicting and measuring language gains in study abroad settings}

As previously noted, test scores alone reveal little about the actual linguistic gains made by students who study abroad. Moreover, the testing instruments themselves may be of concern in that certain well-known tests have been shown to be inappropriate in the study abroad setting, particularly at the more advanced levels. Finally, in considering the benefits that accrue to students from a stay abroad, we often wonder how to best predict success from an academic experience abroad. The work by Brecht et al. and Lapkin et al. address these concerns.

Brecht, Davidson and Ginsberg $(1991,1995)$ and Lapkin et al. (1995) set the stage for further reflection about study abroad by considering factors in a student's prior learning experience which might predict success abroad. They identify, as well, test instruments which are most appropriate to measure these gains. Both studies deal with different student populations in a variety of educational settings. Brecht and his colleagues present the findings from a large, multi-year study of American undergraduates who have spent a semester or more of "in-country immersion (that is, studying Russian in Russia). Lapkin et al. discuss language gains made by a group of Canadian adolescents who have participated in a three-month bilingual interprovincial exchange program. Despite differences in language studied, age of students, program length, and formal language instruction during the program, certain similarities emerge.

Foremost among these similarities are the anticipated findings that students who participate in programs such as these are more likely to reach higher levels of proficiency than are their peers who have not participated in exchange or sojourn abroad programs. In addition, both sets of authors identified certain variables (level of pre-program language proficiency, age, previous in-country immersion) as likely to predict success in the study-abroad or exchange environment. As summarized earlier, a significant finding in the Brecht study is that pre-program reading and 
grammar skills are important predictors of gain in all other skill areas.

Both of these studies (Brecht, Davidson and Ginsberg, 1991, 1995; Lapkin et al. 1995), utilize an extensive package of measurement instruments, including multi-skill tests, questionnaires, self-assessments and/or diary studies. An important result of the Brecht study, reiterated later by Freed (1995c), is the apparent failure of the well-known Modern Language Aptitude Test to predict student gains in speaking and listening in a study abroad context.

A self-assessment questionnaire, unique to the Lapkin et al. study, fails to meet its potential as a surrogate for testing language directly, but provides a new dimension for exploring student perceptions of sociolinguistic gains during an exchange. This is crucially important information for those tempted to use self-report data in lieu of direct measurements of linguistic performance. However, it is valuable to note that despite the failure of the self-assessment data to corroborate more direct testing, the self-assessment data did provide valuable information on the most advanced students in the Lapkin et al. study, information that would have otherwise been lost because of the ceiling effect of tests used.

The issue of ceiling effects is directly related to measurement issues discussed throughout this chapter. The finding by Brecht et al. (reported also by Lapkin et al. 1995; Milton and Meara, 1995; Meara, 1998; as well as by Freed, 1995b among many others), that students with initially lower language proficiency make greater gains in an immersion setting may very well be an artifact of the testing package. To the extent that assessment instruments are unable to capture the progress made by more advanced students, we will always have the impression that it is the lower-level students who have made the greatest gains, at home or abroad.

\section{(2) Comparative studies: language learning abroad and at home}

Moving beyond predictions of gain and questions of measurement, a series of cross-linguistic research projects compare language learning at home and abroad for students at different levels of study. These are among the first studies which offer data, other than test scores, as empirical support for the folk belief in the linguistic advantages of study abroad. As a group, the stories told by these authors (Lafford, 1995; Freed, 1995b; 
Huebner; 1995) provide a beginning description of some specific linguistic features which may differ in the language of these two groups of students.

Lafford's (1995) study is a comparison of the communicative strategies of two groups of study abroad students (one in Mexico, one in Spain) contrasted with a control group on her home campus in the United States. Her analysis is based on the role-play situations which form an inherent part of the OPI (and which tend to approximate encounter situations students find in the target culture). The results which emerge from her study demonstrate clearly that both the abroad groups (the Mexican and Spanish) have a far broader repertoire of communicative strategies for initiating, maintaining, expanding and terminating a communicative situation than do those whose learning has been limited to the formal language classroom. The related finding, that students who have been abroad speak at a faster rate of speech and utilize more repairs in their speech, foreshadows Freed's (1995b) study of fluency.

"Fluency" is one of the most frequently evoked terms in popular discussions of the speech of students who have been abroad. In an attempt to isolate specific qualities of speech that contribute to the long-standing impression of the linguistic benefits of study abroad, Freed (1995b) explores the perceived oral fluency of two groups of undergraduate students (one abroad and one at home) and then goes on to compare linguistically — in the speech of the two student groups - a cluster of features traditionally associated with studies of fluency. Results of her study provide support for the folk belief in study abroad-acquired "fluency." The study abroad students in Freed's study speak both more and significantly faster than those who have not been abroad, and their speech is characterized by a greater smoothness with fewer clusters of dysfluencies and longer streams of continuous speech. Students in Freed's study also exhibited sometimes surprising individual differences on each of the variables studied, similar to the finding first reported by DeKeyser.

Building on Freed's initial study of the oral fluency of study abroad students, Freed and her colleagues (Freed, Lazar and So, 1998; Freed, So and Lazar, 1999) have explored the acquisition of written fluency by the same group of students. One of the few studies that addresses the acquisition of writing skills during a period abroad, Freed and her colleagues have found little support for the presumed assumption that skills in writing change during a semester abroad. Preliminary results of their analyses 
indicate that native speaker judges do not perceive differences in the written fluency of students who have been abroad as compared to those who have not. Moreover, textual analyses that focus on syntactic complexity, grammatical accuracy, lexical density, and structural coherence reveal few if any differences in the writing of these two groups of students.

In contrast to these studies, Huebner (1995) compares two matched groups of American college students who were just beginning the study of Japanese. While statistically significant differences in acquisition patterns do not emerge, due in large part to the small number of students in his population, Huebner uses descriptive statistics, an artful blend of qualitative and quantitative results, to demonstrate trends which are indicative of differences between the two groups. He shows, for example, that the superior performance on the test of reading, by the group studying in Japan, was bolstered by the positive attitudes toward the acquisition of literacy expressed in interviews and journals by the students in this group. Similar tendencies were found with respect to performance on the OPI. Consistent with the results in the Freed and DeKeyser studies, Huebner too finds great variation among learners in the Japan group. The profile Huebner sketches of the experience of language learning for beginning students contradicts prior positions which oppose study abroad at the introductory level.

(3) The acquisition of sociolinguistic competence by students in immersion settings

Among the assumptions regarding language learning in a study abroad setting is the conviction that immersion in the target culture will also exert a major impact on the acquisition of sociolinguistic competence. The work which follows suggests that it is indeed likely that a sojourn abroad will affect a student's ability to vary linguistic forms in accordance with certain social aspects of an encounter situation. A number of studies have now traced changes in the use of a variety of sociolinguistic variables by students who have been abroad, pointing as a group to a series of common patterns in the acquisition of diverse sociolinguistic variables. The following summary is limited to the work of three authors (Marriott; Siegal; and Regan) that first appeared in Freed (1995a). This discussion is followed, in the next chapter, by a more in-depth analysis of issues relat- 
ed to the acquisition of sociolinguistic competence .

Marriott (1995) analyzes the acquisition of politeness in Japanese by eight secondary-level Australian exchange students who spend a year in Japan. As she carefully points out, politeness in Japanese includes use of the honorific system, which consists of grammatical encoding of verbal and other lexical elements, linguistic politeness, and etiquette or courtesy which covers non-verbal behavior. In this study, Marriott uses a role-play situation as the basis for a quantitative analysis of the pre- to postexchange behavior in the use of several of these variables. Three major conclusions are drawn from this study: first, there is great variation in the acquisition of politeness norms among the students in the study; second, students demonstrate considerable change in their use of politeness phenomena after their sojourn in Japan; and finally, their performance still deviates considerably from the expected norm. These observations emerge again in the following studies.

In a study otherwise quite different from Marriott's, Siegal (1995) also chooses the acquisition of politeness as the basis of an exploration of individual differences in the learning of Japanese by U.S. college students. Using a detailed case study of two advanced female learners of Japanese, Siegal presents a qualitative analysis to describe the acquisition of pragmatic (contextual or interactional) and stylistic competence, to demonstrate learner differences in acquisition and to suggest what the basis of these differences are. Siegal brings new insight to the field with her detailed description of the competing pragmatic demands and conflicts faced by her subjects and in their response to these pressures. She demonstrates the ambivalence experienced by each of these women and the way in which each reconciles her desire to speak politely and to maintain her own sense of identity within Japanese society.

In a related study, Regan (1995) has chosen to focus on the acquisition of negation in French, or more particularly on one sociolinguistic variable and how this variable is affected by a stay abroad. In her study, Regan analyzes the deletion of "ne," the first particle of the common negative construction - "ne (verb) pas" - in French. The general finding which emerges from this study is that a stay abroad results in a dramatic change in the acquisition of this sociolinguistic variable. Consistent with native speaker usage, the trend toward "ne" deletion on the part of the students is radically increased after a year abroad. However, deviations from native 
speaker styles are equally apparent. As in numerous other studies cited, Regan's findings demonstrate great individual variation among students.

The results of this study also provide interesting information not explicitly addressed elsewhere: that is, the change in structural or grammatical features in learner language as a consequence of a study abroad experience. In the context of Regan's study, linguistic factors which conditioned the use of "ne" deletion did not change very much in the course of the year. Regan concludes that the stay in the native speech community (at least for her advanced-level learners) seemed to make no difference in the improvement of their strictly "grammatical skills" as distinguished to their growing sociolinguistic competence. Similar results emerge in Freed et al.'s (1998; 1999) studies of writing in a study abroad setting.

\section{(4) Student views of learning abroad}

Research on language learning in a study abroad context has recently been enhanced by a series of qualitative studies which offer a view of study abroad from the perspective of the students who participate in these programs. (Several of these studies which appeared in Freed (1995a) are briefly described below. The articles by Pellegrino, Wilkinson, and Kline in this volume will provide detailed elaborations of this approach to investigating the relationship between second language acquisition and study abroad.) Three separate studies (Brecht and Robinson 1995, Polyani 1995 and Miller and Ginsberg 1995) base their analyses on student diaries and narratives collected within the context of the large Russian project summarized earlier in this paper (Brecht and Davidson, 1991; Brecht, Davidson and Ginsberg, 1995; Ginsberg, Robin and Wheeling 1992; Ginsberg 1992). Individually and as a group they offer valuable insight into how students perceive their time abroad and their own thoughts about how these experiences relate to the language learning process.

Polanyi (1995) explores the controversial finding, which emerged from the large Russian study discussed above, of a possible gender bias with respect to language growth abroad. As Huebner points out (this volume) SLA research suggests that females as a group are better second language learners than males. In contrast to this general pattern, the results of the major Russian study pointed to greater gains made by males in a study abroad setting (at least in the Russian context). Polanyi believes 
that a logical explanation for the conclusion that "women gain less than men in listening and speaking skills," is to be found in the actual experiences reported by female students who had participated in the Russian study abroad project.

In a narrative analysis of stories and reports written in the extensive journals of 40 of the participants (half men and half women) in the larger Russian study, Polanyi finds a pervasive theme of sexist behavior toward the female students which, in their own words, reveals how their linguistic growth has been compromised as a result of the experiences they encounter in the field. In story after story, Polanyi portrays the discomfort of these female students, their self-doubts and frustrations in face of the sexual harassment they encounter. It is these "severe gender-related problems" that Polanyi claims are responsible for the women's lower scores on both tests of listening and oral proficiency. Moreover, not only do women encounter unpleasant gender-related behavior while in the field, but they are further penalized by testing instruments that measure the skills of an "ungendered person (i.e., a male)," while their experience abroad consisted of their "being and speaking, and being spoken to and treated as a person gendered female." In other words, the experiences of these female students, as related by the women themselves, not only inhibit their language learning opportunities but also their ultimate performance on tests which measure their learning.

Miller and Ginsberg (1995), also analyze a sample of student narratives which derive from the larger Russian study. Their analysis of "folklinguistic theories" is based on the ideas students express in their journals about language, the language learning process and methods of language learning. The authors identify several intertwined themes which recur in the students' writings: themes that reveal their narrow but well-developed ideas about what constitutes appropriate linguistic data and what they consider valuable in the language learning process. Among their discoveries is the fact that students are highly critical of what takes place in the formal language learning classroom but, ironically enough, seek to recreate outside of the classroom the opportunities and interactions that classroom instruction offers.

This discovery presents an interesting paradox in many students' treatments of native speakers as participants in their language learning experiments. While they commonly criticize and reject certain pedagogi- 
cal classroom activities, they praise these very same activities when they occur out of class in a native speaker context. The attitudes and beliefs that students have developed affect all aspects of their language learning while abroad. As the authors point out, these beliefs and the behaviors they engender are important, "not for their validity but for their consequences."

Building further on the theme of student perspectives on the relationship between classroom instruction and other arenas for language learning, Brecht and Robinson also explore the perceived value of formal instruction in the study abroad setting by going directly to the learners and seeking their opinions. Based on their contention that research which is based on student opinions is prone to "problems of investigator selection and interpretation," the authors are careful to design a study which analyzes data deriving from different modes of elicitation (observations, interviews, different types of student diaries), collected at multiple points and in different conditions during the study abroad experience. Their analysis reveals an inconsistency in student opinion, one which demonstrates alternating criticism and praise for the classroom experience. Brecht and Robinson conclude that this lack of one unified opinion with respect to the perceived value of formal instruction in an immersion environment is the result of a variety of factors, including where the students are in their study abroad experience, their out-of-class contacts, and their needs of the moment.

As a group, the work of these authors has influenced the direction of more recent studies which explore similar, as well as different, aspects of the linguistic experiences of students who live and study abroad. Since 1995 or so this new series of studies has further expanded the field of language learning in a study abroad context. In many respects these explorations have been inspired by the work of the authors above. Considered together, the more recent work is largely qualitative in focus, utilizing introspective techniques (diaries, interviews, narratives) as well as case studies, ethnographies, etc. to amplify the researchers' understanding of students' language use and the language learning experience. To some extent, this research has also focused on areas that were largely neglected in the past. These include second language literacy, the nature of the immersion context itself as well as enriched explorations of student perceptions themselves. Each of these topics and issues is discussed at length 
by Pellegrino, Wilkinson and Kline in the articles that follow.

\section{Sum ary and Conclusion}

This overview of the relationship between language learning and the study abroad experience suggests that there are indeed differences between the language proficiency of those who have had the opportunity to reside abroad and those whose language learning has been limited to the formal language classroom at home. Much of the research discussed in the context of this chapter brings welcome empirical support to the long-held popular belief in the power of a study abroad experience to profoundly influence the linguistic skills of program participants. At the same time it also offers some unanticipated surprises.

Based on the strictly language-based descriptions we have considered, an emerging profile of the linguistic skills of students who have been abroad might be sketched as follows: Those who have been abroad appear to speak with greater ease and confidence, expressed in part by a greater abundance of speech, spoken at a faster rate and characterized by fewer dysfluent-sounding pauses. As a group, they tend to reformulate their speech to express more complicated and abstract thoughts, display a wider range of communicative strategies and a broader repertoire of styles. It is equally clear that their linguistic identities extend beyond the expected acquisition of oral skills to new self-realization in the social world of literacy.

Nonetheless, we still know relatively little about changes in the structural accuracy of their language. Early reports have suggested, at least for more advanced learners, that significant changes do not take place within the study abroad context. By contrast, students who have been abroad may be expected to acquire a range of native-like sociolinguistic variables. However, their use of these forms sometimes remains deviant, often in their over-generalization or misuse of certain forms. Of particular interest is the highly developed meta-cognitive awareness of sociolinguistic differences demonstrated by some students in response to potentially conflicting pragmatic demands. Perhaps in contrast to the classroom learner, these students possess a set of well-defined, if sometimes inaccurate, beliefs about what constitutes appropriate linguistic data and language learning methodology.

Beyond these linguistic competencies, it is also clear that the popu- 
lar notion of the study abroad environment is not as uniform as was once believed. Student perceptions of their experiences have taught us that their interactions with native speakers may be far less intense and frequent than was once assumed and that the so-called "immersion" into the native speaker linguistic environment may be somewhat less guaranteed than was once taken for granted. At the same time, individual differences have been shown to be highly influential in the experiences that students have while abroad. Their perceptions of the language learning environmentboth in class and out - have demonstrated a profound impact on the way in which they go about manipulating the linguistic environment, often to their advantage but sometimes to their disadvantage.

Extending the discussion beyond the linguistic impact of study abroad experiences on the students themselves, there is preliminary evidence that responds to a number of issues related to applied programmatic concerns. If the findings of initial studies are replicated, there is good reason to believe that study abroad opportunities should not necessarily be limited to students who are at the intermediate and advanced levels. There is also added support for the impression that the greatest gains in an immersion environment are made by students with initially lower language proficiency.

This last finding, however, must be interpreted within the context of general language assessment. Throughout these and prior studies we have been confronted by the failure of various measurement instruments to capture adequately the language growth of more advanced students. Until more finely-tuned testing instruments have been developed and applied in the field, we should approach with caution any conclusion suggesting limitations on the potential growth of more advanced students in a study abroad setting. By the same token, we seem to have ample evidence that the long used MLAT is of less value than previously suspected in predicting gains in certain areas of language study.

Finally, the variety of research procedures and methods of analysis utilized by scholars working in this area provide convincing support for the advantages of what Erickson (1991) has called interpretive research. The integration of quantitative and qualitative research design and analysis which permits descriptive interpretation of results, complements and enriches our understanding of language learning that takes place in a study abroad context. 
Although we have gained recent insights into the relationship between language learning and study abroad experiences, much more remains to be uncovered. We have yet to learn about the long-term effect of time spent abroad on language competence. If we can generalize from Raffaldini's (1987) and Coleman's (1996 and this volume) findings, it appears that the period just after students return to their home country marks the high point of second language proficiency, which can thereafter decline. Research on second language acquisition in the study abroad setting will also continue to deepen our understanding about the process of second language loss and what might be done to delay the attrition of the second language competencies students have worked so hard to gain.

Of the numerous applied implications of study abroad learning, few are as compelling as the recognition of efforts that must be made to help students maintain their hard-won skills, primarily by encouraging them to seek opportunities for continued language use. These options present themselves in numerous untapped ways: among the numerous ethnic minorities and international residents in American cities today, among the growing numbers of international students who study on American campuses, by increased technological opportunities, as well as, more obviously, by continuing to read second language texts and tuning in to the growing number of second language television and radio programs that are to be found across our country.

Given the increasing emphasis of American institutions of higher education to provide international dimensions to their curricula, we are certain to see growing numbers of students spend some portion of their undergraduate careers in a foreign destination. Acknowledging the rich diversity of programs and the individuality of student interests and strengths, it is impossible to establish a one-to-one correlation between program type and student growth. It is equally clear that the degree and depth of personal growth, as well as linguistic and cultural impact, will vary enormously from student to student and experience to experience. The recent emergence of studies which analyze the linguistic impact of study abroad experiences has deepened our understanding of the language gains made by students who are able to participate in these programs. The most recent of these works have also made us consciously aware of some of the myths associated with the study abroad experience and sensitized us to the weakness of some of these long-held assumptions about the study 
abroad experience. With this increased awareness it should be possible to usher the next generation of American students into the international programs which best suit their needs, and to reap the benefits that will accrue to the country at large as a larger segment of our population recognizes and develops pride in the benefits of speaking a second language.

\section{Notes}

1 Portions of this chapter appeared previously in Freed, 1995a.

\section{References}

ACTFL. 1986. ACTFL Proficiency Guidelines. New York: The American Council on the Teaching of Foreign Languages.

Baron, B. \& A. Smith (eds.) 1987. Higher Education in the European Community. Study Abroad in the European Community. Luxembourg.

Brecht, R., D. Davidson, \& R. Ginsberg. 1990. The empirical study of proficiency gain in study abroad environments of American students of Russian. American contributions to the VII International Congress of MAPRIAL ed. by D. Davidson. Washington, D.C.: American Council of Teachers of Russian. 123-52.

Brecht, R.D. \& D. Davidson. 1991. Language acquisition gains in study abroad: Program assessment and modification. Paper presented at the NFLC Conference on Language Testing, Washington D.C. March, 1991.

Brecht, R., D. Davidson, \& R. Ginsberg. 1993. Predictors of foreign language gain during study abroad. Washington D.C.: National Foreign Language Center.

Brecht, R. \& J. L. Robinson. 1993. Qualitative analysis of second language acquisition in study abroad: The ACTR/NFLC Project. Washington D.C.: National Foreign Language Center.

Brecht, R., D. Davidson \& R. Ginsberg. 1995. Predicting and Measuring Language Gains in Study Abroad Settings. Second Language Acquisition in a Study Abroad Context. ed. by B.F. Freed, 37-66. Amsterdam /Philadelphia: John Benjamins Publishing Company.

Brecht, R.D. \& J. L. Robinson. 1995. On the value of formal instruction in study abroad: Student reactions in context. Second Language 
Acquisition in a Study Abroad Context. ed. by B.F. Freed, 317-334. Amsterdam /Philadelphia: John Benjamins Publishing Company. Bryam, M. 1988. A Year in France. Durham. University of Durham. Carlson, J., B. Burn, J. Ussem \& D. Yachimowicz. 1990. Study abroad: The Experience of American Undergraduates in Western Europe and the United States. Westport, Conn.: Greenwood Press.

Carroll, J.B. 1967. Foreign language proficiency levels attained by language majors near graduation from college. Foreign Language Annals 1: 131-151.

Coleman, J. 1996. A comparative survey of the proficiency and progress of language learners in British universities. In Der C-Test. Theoretische Grundlagen und prakische Anwendungen. ed. by R. Grotjahn. Bochum, Brockmeyer volume 3: 367-399.

Coleman, J. 1997a. Supporting language students during their year abroad (with Bill Brierley), The Linguist, vol.36, .1:2-5.

Coleman, J. 1997b. Residence abroad within language study. Language Teaching, 30, 1:1-20.

Coleman, J. Language Learning and Study Abroad: The European perspective. This Volume

Coleman, J. \& A. Rouxeville (eds.) 1993. Integrating new approaches. Association for French Studies in association with the Center for Information on Language Teaching and Research. Bedfordbury, London.

Coleman, J., R. Grotjahn, C. Klein-Braley \& U. Raatz. 1994. The European language proficiency survey: a comparative investigation of foreign language learners in schools and universities in several European countries. Language Testing Update.

Clement, L. R. 1978. Motivational characteristics of francophones learning English. Quebec: Centre International de Recherche sur le Bilinguisme.

Dalichow, F. \& U. Teicher. 1986. Higher Education in the European Community. Recognition of study abroad in the European Community. Luxembourg.

DeKeyser, R. 1986. From learning to acquisition? Foreign language development in a U. S. classroom and during a semester abroad. Unpublished Ph.D. Dissertation. Stanford U.

DeKeyser, R. 1991. Foreign language development during a semester 
abroad. Foreign Language Acquisition Research and the Classroom ed. by B. Freed, 104-119. Lexington, Mass.: D. C. Heath \& Co.

Desruisseaux, P. 1996. A record number of foreign students enrolled in U.S. last year. Chronicle of Higher Education. December 6, 1996. A64. Desruisseaux, P. 1997.The number of Americans studying abroad increases by $5.7 \%$. Chronicle of Higher Education. Dec. 12, 1997. A44-46.

Dyson, P. 1988. The year abroad. Report for the Central Bureau for Educational Visits and Exchanges. Oxford University Language Teaching Centre.

Foltz, D. 1991. A study of the effectiveness of studying Spanish overseas. Paper presented at the Pennsylvania State Modern Language Association Annual Meeting, Pittsburgh, PA.

Freed, B. 1990. Language learning in a study abroad context: The effects of interactive and non-interactive out-of-class contact on grammatical achievement and oral proficiency. Linguistics, Language Teaching and Language Acquisition: The Interdependence of Theory, Practice and Research ed. by J. Atlatis, 459-477. Georgetown University Round Table on Languages and Linguistics. Washington D. C.: Georgetown University Press.

Freed, B. (ed.) 1991. Foreign Language Acquisition Research and the Classroom. Lexington, Mass.: D.C. Heath \& Co.

Freed, B. 1994. Assessing the linguistic impact of study abroad: What we currently know - what we need to learn. Journal of Asian Pacific Communication 4:4, 151-166.

Freed, B. 1995a. Second Language Acquisition in a Study Abroad Context. Amsterdam /Philadelphia: John Benjamins Publishing Company.

Freed, B. 1995b. What makes us think that students who study abroad become fluent? Second Language Acquisition in a Study Abroad Context ed. B.F. Freed, 123-148. Amsterdam/Philadelphia: John Benjamins Publishing Co.

Freed, B., N. Lazar \& S. So. 1998. Fluency in writing: Are there differences between students who have studied abroad and those who have not? Presented at the annual meeting of the Modern Language Association. December, 1998. San Francisco, CA.

Freed, B., S. So \& N. Lazar. Perceptions of oral and written fluency in second language use. To be presented at the annual meeting of the American Association of Applied Linguistics. March, 1999. 
Stamford, Ct.

Gardner, R. Glicksman \& Smyth. 1978. Attitudes and behaviour in second language acquisition: a social psychological interpretation. Canadian Psychological Review 19: 173-186.

Ginsberg, R., R. Robin \& P. Wheeling. 1992. Listening comprehension before and after study abroad. National Foreign Language Center Working Papers. Washington D.C.: National Foreign Language Center.

Ginsberg, R. 1992. Language gains during study abroad: An analysis of the ACTR data. National Foreign Language Center Working Papers. Washington D.C.: National Foreign Language Center.

Goodwin, C. \& M. Nacht. 1988. Abroad and beyond: Patterns in American overseas expansion. Cambridge: Cambridge U. Press

Guntermann, G. 1992a. An analysis of interlanguage development over time: Part I, por and para. Hispania 75:177-187.

Guntermann, G. 1992b. An analysis of interlanguage development Over Time: Part II, ser and estar. Hispania 75:1294-1303.

Guntermann, G. 1995. The Peace Corps Experience: Language Learning in Training and in the Field. Second Language Acquisition in a Study Abroad Context ed. by B.F. Freed, 149-169. Amsterdam /Philadelphia: John Benjamins Publishing Company.

Hanna G, A.H. Smith, L.D. McLean, \& H.H. Stern. 1980. Contact and communication: An evaluation of bilingual student exchange programs. Toronto, Canada: OISE Press.

Hashimoto, H. 1994, Language acquisition of an exchange student within the homestay environment. Journal of Asian Pacific Communication 4(4):209-224.

Hart, D.S., S. Lapkin \& M. Swain. 1994. Impact of a six-month bilingual exchange program: Attitudes and achievement. Report to the Department of the Secretary of State. Toronto: OISE Modern Language Centre.

Huebner, T. 1991. Effects of overseas study: A preliminary report on an intensive beginning-level course in Japanese. Paper presented at the annual PACIE Conference, Pittsburgh PA.

Huebner, T. 1995. The Effects of Overseas Language Programs: Report on a Case Study of an Intensive Japanese Course. Second Language Acquisition in a Study Abroad Context ed. by B.F. Freed, 171-193. Amsterdam /Philadelphia: John Benjamins Publishing Company.

Huebner, T. 1998. Methodological considerations in data collection for 
language learning in a study abroad context. This Volume

Inkster, G. 1993. Integrating the year abroad. Integrating new approaches ed. by J. Coleman \& A.Rouxeville. 133-145. Association for French Studies in association with the Center for Information on Language Teaching and Research. Bedfordbury, London.

Johnson, S.J. \& R.J. Edelstein. 1993. Beyond borders: Profiles in international education. Washington, D.C. Association of American Colleges and American Assembly of Collegiate Schools of Business

Kaplan, M. 1989. French in the community: A survey of language use abroad. The French Review 63:2 (290-301).

Kline, R. 1993.The social practice of literacy in a program of study abroad. Unpublished Ph.D. dissertation. The Pennsylvania State University.

Kline, R. Forthcoming. The acquisition of second language literacy in a study abroad context. This Volume.

Klein, W. 1986. Second language acquisition. Cambridge: Cambridge University Press.

Koester, J. 1985. A profile of the U. S. student abroad. New York: Council on International Exchange. 22.

Lafford, B. 1995. Getting Into, Through and Out of a Situation: A Comparison of Communicative Strategies Used by Students Studying Spanish Abroad and 'At Home.' Second Language Acquisition in a Study Abroad Context ed. by B. F. Freed, 97-121. Amsterdam /Philadelphia: John Benjamins Publishing Company.

Lapkin, S. D. Hart \& M. Swain. 1995. A Canadian Interprovincial Exchange: Evaluating the Linguistic Impact of a Three-Month Stay in Quebec. Second Language Acquisition in a Study Abroad Context ed. by B. F. Freed, 67-94. Amsterdam /Philadelphia: John Benjamins Publishing Company.

Laubscher, M.R. 1994. Encounters with difference: Student perceptions of the role of out-of-class experiences in education abroad. Westport, CT: Greenwood Press.

Liskin-Gasparro, J. 1984. Comparison of the oral proficiency of students of Spanish in a study abroad program and those in regular academic programs. As quoted in Liskin-Gasparro and Beyer, 1987.

Magnan, S. S. 1986. Assessing speaking proficiency in the undergraduate curriculum: Data from French. Foreign Language Annals 19.5: 429-38. 
Marriott H.E. 1993a. Changing trends in Australia-Japan and JapanAustralia student exchanges and study abroad programs. Paper presented at Celebrate Australia Educational Exchange Programs Forum, Tokyo, November 1993.

Marriott H.E. 1993b. Acquiring sociolinguistic competence: Australian secondary students in Japan. Journal of Asian Pacific Communication 4:4, 167-192.

Marriott, H.E. 1995. The Acquisition of Politeness Patterns by Exchange Students in Japan. Second Language Acquisition in a Study Abroad Context ed. by B.F. Freed, 197-224. Amsterdam /Philadelphia: John Benjamins Publishing Company.

Marriott. H. and S. Enomoto. 1995. Secondary exchanges with Japan: exploring students' experiences and gains. Australian Review of Applied Linguistics Series S, 12, 64-82.

Mauranen, A. \& R. Markkanen. 1994. Students Abroad: Aspects of exchange students' language. Finlance XIII

Mauranen, A. 1994. Two discourse worlds: Study genres in Britain and Finland. Finlance XIII: 1-40.

Meara, P. 1994. The year abroad and it effects. Language Learning Journal, $10,32-38$.

Meara, P. 1998. The year abroad: an opportunity or a nightmare? Manuscript.

Miller, L. \& R. Ginsberg. 1995. Folklinguistic Theories of Language Learning. Second Language Acquisition in a Study Abroad Context ed. by B.F. Freed, 293-315. Amsterdam /Philadelphia: John Benjamins Publishing Company.

Milleret, M. 1990. Assessing the gain in oral proficiency from summer foreign study. Paper Presented at the Summer Meeting of AATSP.

Milton, J and P. Meara, 1995. How periods abroad affect vocabulary growth in a foreign language. Review of Applied Linguistics, 107-108: $17-34$.

Möhle, D. 1984. A comparison of the second language speech of different native speakers. Second language productions ed. by H. Dechert et al. Tübingen: Gunter Narr. 26-49.

Möhle, D. \& M. Raupach. 1983. Planen in der Fremdsprach. Frankfurt: Peter Lang.

O'Connor, N. 1988. Oral proficiency testing of junior year abroad: 
Implications for the Undergraduate curriculum. Paper presented at the 1988 Annual Meeting of the MLA

Pellegrino. V. 1997a. Social and psychological factors affecting spontaneous second language use during study abroad: A qualitative study. Unpublished Ph.D. dissertation. Bryn Mawr College.

Pellegrino. V. 1997b. speaking abroad: How interpersonal relations affect American students' use of Russian beyond the classroom. MLA Convention, Toronto, Canada. December 29, 1997.

Pellegrino. V. 1998. Student perspectives on language learning in a study abroad context. This Volume.

Polanyi, 1995. Language Learning and Living Abroad. Second Language Acquisition in a Study Abroad Context ed. by B.F. Freed, 271-291. Amsterdam /Philadelphia: John Benjamins Publishing Company.

Raffaldini , T. 1987. Attrition of communicative ability among former year abroad students of French. Unpublished Ph.D. dissertation, Indiana University.

Raupach, M. 1984. Formulae in second language speech production. Second language productions. H. Dechert et al., 114-37. Tubingen: Gunter Nair.

Raupach, M. 1987. Procedural learning in advanced learners of a foreign language. Duisburg; Universitat Gesamthochschule Duisburg. (L.A.U.D. Papers B 167).

Regan, V. 1998. Sociolinguistics and language learning in a study abroad context. This Volume.

Regan, V. 1995. The Acquisition of Sociolinguistic Native Speech Norms: Effects of a Year Abroad on Second Language Learners of French. Second Language Acquisition in a Study Abroad Context ed. by B.F. Freed, 245-267. Amsterdam /Philadelphia: John Benjamins Publishing Company.

Ryan, J. M. \& Lafford, B. 1992. Acquisition of lexical meaning in a study abroad environment: ser and estar and the Grenada experience. Hispania 75: 714-722.

Siegel, M. 1995. Individual Differences and Study Abroad: Women Learning Japanese in Japan. Second Language Acquisition in a Study Abroad Context ed. by B.F. Freed, 225-243. Amsterdam /Philadelphia: John Benjamins Publishing Company.

Teichler, U. \& W. Steube 1991. The logics of study abroad programmes 
and their impacts. Higher Education. 21, 325-349.

VanPatten, B. 1987. Classroom learners' acquisition of ser and estar: Accounting for developmental patterns. Foreign language learning: A research perspective ed. by B. VanPatten, T.R. Dvorak and J.F. Lee, 1932. Cambridge: Newbury House.

Veguez, R. 1984. The oral proficiency interview and the junior year abroad: Some unexpected results. Paper presented at the Northeast Conference on the Teaching of Foreign Language. NYC April 1984.

Wilkinson, S.1995. Foreign language conversation and the study abroad transition: A case study. Unpublished Ph.D. dissertation. The Pennsylvania State University.

Wilkinson, S. 1998. Study abroad from the participants' perspective: A challenge to common beliefs. Foreign Language Annals 31 (1) 23-39.

Wilkinson, S. 1998. The nature of immersion during study abroad: Student perspectives. This Volume.

Willis, F., G. Doble, U. Sankarayya. \& A. Smithers. 1977. Residence abroad and the student of modern languages. A preliminary study. Bradford: Modern Language Centre. U of Bradford.

Ylönen S. 1994. Die Bedeutung von Textsortenwissen fur die interkulturelle Kommunikation - Kommunikative Unterschiede im Biologiestudium an den Partneruniversitaten Jyvaskyla und Bonn. Finlance XIII: 89-113. 